\section{SOI: $1.1 /$ TAS DOI: $10.15863 /$ TAS International Scientific Journal Theoretical \& Applied Science}

p-ISSN: 2308-4944 (print) e-ISSN: 2409-0085 (online)

Year: 2015 Issue: $10 \quad$ Volume: 30

Published: $30.10 .2015 \quad$ http://T-Science.org
Nilufar Xodjakbarovna Mannanova

Researcher,

Faculty of social sciences

Department "Sociology and social work"

The Mirzo Ulugbek National University of Uzbekistan naumenko06@mail.ru

SECTION 24. Sociological research.

\title{
THE DEVELOPMENT OF PROFESSIONAL COMPETENCE THROUGH DISTANCE EDUCATION
}

Abstract: In this article some aspects of professional development for distance education are considered. Great value in this process is training, training and retraining in the sphere of professional education.

Key words: professional competence, professional education, training, professional development, distance education and learning, methods of learning, information society.

Language: English

Citation: Mannanova NX (2015) THE DEVELOPMENT OF PROFESSIONAL COMPETENCE THROUGH DISTANCE EDUCATION. ISJ Theoretical \& Applied Science 10 (30): 53-57.

Soi: http://s-o-i.org/1.1/TAS-10-30-14 Doi: crossef http://dx.doi.org/10.15863/TAS.2015.10.30.14

Today distance education (DE) as the synthetic model has unique features not found in any of the existing methods and which due to the uniqueness of the vocational education system. In the field of distance education collected the most effective educational approaches aimed at obtaining professional education. Association of benefits, mainly such educational methods and directions, as online education, contextual learning, studentcentered education, can successfully receive the distance vocational education.

In the Republic of Uzbekistan on 12 June 2015 the Decree of the President of the Republic of Uzbekistan Islam Karimov "On measures on further improving system of retraining and advanced training of managerial and pedagogical personnel of higher educational institutions" was claimed. In particular, in the Decree reads: "In order to radically improve the quality of training of highly qualified specialists on the basis of permanent development of their professional level and qualifications of teaching staff of higher education institutions, the implementation of an improved system for regular retraining in accordance with modern requirements:

1. Be considered the most important areas for improvement of system of retraining and advanced training of managerial and pedagogical personnel of higher educational institutions:

- improving on a regular basis the pedagogical and professional level of professors and teaching staff of universities, in-depth study of the norms of legislation, recent advances in theory, research and applied research, technological progress and innovation on the disciplines, as well as modern methods of organization of educational process;

- a major renewal of qualification requirements, curricula, programmes and methods of retraining and advanced training of pedagogical staff of universities taking into account the widespread introduction of modern highly effective and innovative educational technologies, advanced foreign experience;

- mastering by universities teachers and active introduction in educational process of modern innovative pedagogical, information and communication technologies using the global Internet, multimedia systems and techniques of distance learning;

- increasing of the level of practical knowledge of teaching staff of higher education institutions foreign language and its wide use for the steady growth of their professional skills in teaching and research activities" [3].

What awaits the state and society from the vocational education system, a social order to it? The system of professional education must be a means of personality development, organizations and society as a whole and to meet the following requirements of the society:

- to facilitate self-identification and selfrealization;

- to create conditions for the continuous development of universal abilities of the individual to different types of activities (thinking, tutoring, communication, reflection); 
- to build support for socio-professional communicative environment;

- to serve the career development and professional mobility of specialists;

- to assist in a quick and professional retraining of personnel and acquisition of necessary knowledge and skills;

- to be an integral part of the process of improving organizations by increasing human capital via multi-tiered, variable, flexible system of educational programs;

- to create practical orientation of educational programs;

- to provide free and easy access of all segments of the population and specialists of different levels in education.

About the new technology we can say the following:

- combines the advantages of educational models and achievements of human civilization;

- directed on vocational education that best meets the expectations of customers and consumers of educational services (individuals, organizations, States, societies);

- a new form of vocational education is offered in a structured way, in the form of multiple separate modules, learning using modern Internet technologies more integrated and more uniform than traditional classroom training. Different teaching methods can be used in various combinations. For example, students can read print materials, discuss them and ask questions in the forum, chat, obtain a videos or graphic images, to run the tests on the Internet, and also via the Internet send works to the teacher.

The main idea of the synthesis of approaches to education can be considered one of the main ideas of distance learning.

DE has the following advantages compared to other learning methods:

Explanatory-illustrative training:

- transmission and memorization of large amounts of information;

- ability simultaneously by using one teacher to teach large number of students;

- effective learning to solution of standard tasks and actions on the sample.

Behavioral-technological training:

- the need for clear goal-setting;

- adaptability of the educational process;

- effective skills training, behavioral systems;

- the use of telecommunicate and information technologies.

Problem-based learning:

- The student is the subject, occupying active position of the researcher;

- the leading principle of the organization of content and learning activity;

- the principle of topicality;
- development of student thinking.

Contextual learning:

- connection of advantages of troubled and pragmatic approaches;

- organization of educational process in accordance with the model of the dynamic movement of activity from training activity to quasiprofessional and then to professional;

- the idea of context: educational activity embedded in the context of socio-professional activity, the learners receive knowledge from the future.

Student-centered learning:

- holistic view on the student as a person, focus on needs, personal experience and the level of his actual development and construction of the educational process in the zone of proximal development of the learner;

the development of universal (interdisciplinary) abilities of the individual, primarily cognitive, creative, communicative, reflexive, as the foundation of professionalism;

- the cyclical organization of education: problematic situation - the situation analysis and problem definition - problem solving - reflection of solutions and self-changes.

Andragogical training:

- connecting learning and work: embedding learning into the framework of the socio-professional activity;

- focus on the needs and real professional problems of students; training;

- considering the peculiarities of vocational

- cycling of the training: the experience analysis - abstract conceptualization experimentation.

The unifying framework of the educational model of DE that allows us to integrate the ideas of these six benefits and improve the quality of vocational education, is orientation when you build the educational process on the competence approach [2].

As a "unit" of measurement of results of the educational process the choice such exponential characteristics of professionalism as "competence", depending on teachers of vocational education is made. Competences or competence are concepts of collective, integrative. Competence is the combination of personal qualities of the student that determines his willingness to focus, to understand and to act effectively in a constantly changing world. Competence cannot simply pass, and you want to turn out yourself. It requires more independence from the student. Implementation of academic disciplines in the logic of the competence approach involves the individualization of the learning process [1]. 
There are different views on the composition of the components of competence. A number of concepts such as components sees knowledge, skills, abilities and attitudes of individuals. In other approaches and conditions are accepted such qualities of competence, knowledge, ability to act, ability to understand, hold all of this. There are other opinions on the components of competence. They are all self-sufficient from the point of view of the justification of the generalized characteristics of professionalism and are appropriate for different conditions of activity.

The content of components of competence by specific properties indicating a particular level of professionalism. The conversation is about the establishment of the amount of knowledge, multiple skills and other things, which must have a specialista professional in a particular field, for example, received technical or liberal education remotely.

The building some reasonable level of competence on the basis of the general characteristics of its components allows to build a "ladder" career path for students and to create an educational program in accordance with the level of competence. Professionalism includes certain human technologies, e.g. technology of materials processing and technology of teaching, design of machinery, ownership of property of pharmacology.

However, in addition to technological competence involves training a large number of other components having largely outside professional or over professional features, but at the same time necessary today in one way or another to anyone. These are such fundamental qualities as autonomy, the ability to make responsible decisions, creative approach to any business, the ability and desire to bring it to the end, the ability to constantly learn. This flexibility and lateral thinking, the presence of abstract, systematic and experimental thinking. This, as well are the skills of dialogue and communication, collaboration, etc. Over the professional technological training is built huge outside professional add-in requirements for specialist.

Reliance on the competence approach to education gives distance education a special quality. This is manifested in the constructive nature of the goal setting in the development of educational material for students, usability of educational technologies and other components of educational activities. The top of the goal-setting become not knowledge, abilities or skills of the student, but the levels of competence of the expert, that is, the educational process begins and ends in professional activity.

That is why the system of distance education of adults has the ability to affect real change not only on a personal level, but also at the level of the organization and society as a whole. Real implementation of the competence approach and the next feature of DE is the idea of integration of the three environments, which is reproduced below:

Learning environment. It is formed during the classes with the students when studying the course materials. This environment is built from different types and forms of training sessions.

Professional environment. It is born from those tasks, discussions, issues that arise in the profession and supported the students during the educational process.

Social environment. It is formed of a plurality of different meetings, business and non-business conversation of students and tutors, in which the socialization activity of students and educational programs. Such an environment is expressed in active communication of students and tutors, during which there is an exchange of knowledge, experience, problems. This part of the educational process equals to those of the classroom.

The creation of three heterogeneous environments in the system of distance education compares the educational process of a kind of club. Many of the students on this occasion it is said that "It's not so much education, how much communication, in which you grow up". In recent years, according to some foreign experts about $70 \%$ of the students in the world choose DE abroad [1].

Distance education is created as a system that combines educational space in several heterogeneous environments the existence of listeners, in which the education is provided.

The principles of distance education as a special form of vocational education is manifested in the activity of educational institutions of DE a variety of opportunities for students. DE develop students as specialists in a particular profession and as individuals, and also contributes to the development of organizations in which learning systems DE is worked.

Below are the basic principles of DE:

- the active-based character of education;

- education through the creation of a friendly environment;

- education through a combination of "soft" and "hard" teaching methods;

- education through interaction of individuals;

- education in open communicative environment;

- education through the creation by students individual educational product;

- education in the space of multi-level programs;

- education through special didactic principles.

Activity-based character of education (or the principle of activity) is reflected in the active side of distance education takes precedence over information. This shows the following:

- the training materials built around the core activity of students; 
- organization of educational process is based on the reflection of the real operations in the business;

- organization of training process built on reflection of the students personal experience and results of their learning activities and a focus on the growth and development of professional competence of a specialist.

Education by creating a friendly environment (otherwise the principle of the formation of stimulating friendly environment) is not only constructive basis from an educational point of view, but also psychological.

The friendly character of education, cooperative relationship between tutors and students remove psychological barriers to learning and education. It is possible to carry out certain communications on the Internet that allows you to remove the psychological barriers (fear of responsibility and fear of failure) and eventually aimed at the emancipation of students.

Education through a combination of "soft" and "hard" teaching styles or forms of control cognitive activity of students is expressed in the following: management of the cognitive activity has a "soft" forms (situational management) where information technology can be applied is limited, the auxiliary functions. However, where it is expected to be learning at the levels of "know", "own", used more "hard" control of cognitive activity, as a leading applied information technology.

Education through interaction of individuals (or indirect method of personal interaction) is that in the system of distance education required element is a direct contact of the student and the tutor, as the only "real" communication can:

- to monitor the dynamics of changes in the needs of the student and the trajectory of his development;

- to carry out examination of the results of creative activity, solving non-standard situations;

- to help the development of creative, communicative and reflective abilities.

In a broad sense, this is manifested as education, based on the interaction of personalities.

Education in an open communicative environment (the principle of openness of communicative space) is manifested in distance education as multifaceted. Organization of distance learning process through interactive and operational activity through the use of computer telecommunications, conferences, email exchanges, etc. promotes openness of communications, from the point of view of accessibility created by students of the educational product. This gives additional opportunities to discuss performance of students and provide feedback in the form of recommendations for development of the established educational product. In distance education fundamentally supports free communication between all participants in the educational process.

Education through the creation of own individual educational product is expressed that under conditions of a sharp increase in the amount of information available on the Internet and on electronic media, the goal of the student becomes not memorization, but the selection, the construction of learner-centered content corresponding to the personal needs of each. This immediately creates specific difficulties for the tutor, because he has always to work with a good individual consciousness and approach of the learner. But this corresponds to a developmental approach to education. Furthermore, the use of a variety of means - graphics, animation, sound and color, special effects, hypertext - allows showing and developing the individual creative approach to established products.

Education in the space of multi-level programs (or the layering of educational programs) is not a special principle of distance education, but here is considered as obligatory condition of activity of educational institution. This creates the opportunity for continuing education, extended student participation in the educational environment; select an appropriate level of education, vision for the future of own education, etc.

Education through special didactic principles is one of the key properties of distance education.

Organization of joint activity of the tutor and students is based on the following didactic principles:

- practical orientation of educational content and methods of collaboration between students and tutors;

- consistency and integrity of the educational content and activity;

- activity and independence of students as the main subjects of education;

- problem orientation and dialogue on the content and nature of interaction in educational process;

- reflexivity as a specially organized activity aimed at studying the awareness of the content, ways of working and, most importantly, their own changes;

- variability (diversity) of the content of education by demonstrating a variety of points of view on subjects of education and the many faces of solving practical and theoretical problems;

- support the motivation of learning;

- collectivity - the predominant role of group learning in both real and in the virtual environment;

- modular organization of educational content and students' activity [2].

The above advantages of distance education are creating some significant opportunities for the learner:

- education without discontinuing work and at home, whom it is impossible during the day to give 
time for visiting of classes, lectures, moreover, geographically, the school may be located quite far;

- distance education is to individuals who have secondary, specialized secondary education, incomplete higher education;

- distance education is designed for those individuals who for various reasons are not able to study directly at universities under the control of the teacher, but tend to get an education. Affordable cost of distance learning provides the opportunity to get an education to everyone, regardless of status;

- one of the obvious features of distance education expressed by the fact that each student masters the course at his own rate. Thus distance education for those people, each person has a special kind of highly individual experience rate. Some students are hearing the lecture immediately aware of main ideas of themes, and some reading independently several times (repeating) is aware of the essence of this lecture. Also, the visual information remains longer in the memory of a person and helps one to understand the essence of the lesson. According to this preferable DE also explained with the use of electronic textbooks, audio visual complex lectures.
In addition DE as a unique form of vocational education training still allows students to take the following options:

- development of own activity;

- development of the brink of their professional competence, where it is most needed;

- education without negative psychological effects;

- sense of himself as a significant actor in the new environment;

- opportunity to find business partners with like-minded colleagues;

- gain a broad and specific understanding of the possible problems in a professional environment through immersion in the diverse experience of fellow learners;

- receive individual consultations on the development of course content;

- personal development and more [2].

It is seen that distance education is one of the effective systems of training, having great prospects in the future. Active dissemination of distance learning is the response of education systems to the processes of integration, the movement towards the information society.

\section{References:}

1. Golysheva MD, Didenko AV, Vlasova MV, Asadullina LI (2015) E-learning i distancionnoe obrazovanie v Rossii i za rubezhom: problemy i puti reshenija. Available: www.gramota.net/materials/2/2011/4/12.html (Accessed: 20.10.2015).

2. (2015) http://vfmgiu.ru/zaochnoe/osob-distobuch/index.html (Accessed: 20.10.2015).

3. (2015) Ukaz Prezidenta Respubliki Uzbekistan O merah po dal'nejshemu sovershenstvovaniju sistemy perepodgotovki i povyshenija kvalifikacii rukovodjashhih i pedagogicheskih kadrov vysshih obrazovatel'nyh uchrezhdenij. Available: http://pressservice.uz/ru/document/5132/ (Accessed: 20.10.2015).

4. (2015) The short history of Distance Education development Available: http://dtraining.web3.ru/introduction/history/

(Accessed: 20.10.2015).
5. Pulatov B (2015) The forms, history and international experience of the Distance Education. Available: http://www.huquqgazeta.uz/index.php/article/id/564/ (Accessed: 20.10.2015).

6. Monahov VM (2003) Evolution of distance education and theoretical basement of building instrumental model (in the example of entrance course) Dis. Can. Ped. Sci. M 2003.

7. Schennikov SA (2003) Development of open professional Distance Education. Dis. Of doc. Of ped. Sci. - M, 2003.

8. Ruliene LN (2010) Distance Education: essence, problems, perspectives. Monograph. Ulan-ude. Buryatsk State University Publishment, 2010. Page 9.

9. Libin-Levav VA (1998) Theory and practice of Distance education: Open University of Israel Dis. Can. Ped. Sci. M, 1998.

10. Nikishov AA, Syulnikova NV (2008) Innovative technologies of distance education in rural areas. Tutorial. Moscow. 2008. Page 6. 